\title{
Report of the Proceedings of the Livingstone Congo Expedition
}

\section{Author(s): W. G. Grandy}

Source: Proceedings of the Royal Geographical Society of London, Vol. 19, No. 2 (1874 1875), pp. 78-105

Published by: Wiley on behalf of The Royal Geographical Society (with the Institute of British Geographers)

Stable URL: http://www.jstor.org/stable/1799810

Accessed: 25-06-2016 23:06 UTC

\footnotetext{
Your use of the JSTOR archive indicates your acceptance of the Terms \& Conditions of Use, available at

http://about.jstor.org/terms
}

JSTOR is a not-for-profit service that helps scholars, researchers, and students discover, use, and build upon a wide range of content in a trusted digital archive. We use information technology and tools to increase productivity and facilitate new forms of scholarship. For more information about JSTOR, please contact support@jstor.org.

The Royal Geographical Society (with the Institute of British Geographers), Wiley are collaborating with JSTOR to digitize, preserve and extend access to Proceedings of the Royal Geographical Society of London 
himself a task which already smacked of something like completeness. Lake 'langanyika had not previously been coasted all round. Livingstone did his best; but in his last days he was failing, and could not settle the question of the outlet, although in his journal, and on the map which had come home, he stated his belief that there was an outlet from the lake on the western side. Lieut. Cameron seemed to have set about his work in the right way. First of all, he had gone down the East Coast, and then passed on to that portion of the West Coast which he knew the Doctor had not surveyed. As the letter stated, when Livingstone sailed along that coast it was in the night, and he was so prostrate that he was unable to take any observations or even to put questions to the natives. Still there were difficulties to be met with in Lieut. Cameron's account. The letter was written on the 15th May, when he had returned from exploring the outlet, just at the very time when the heaviest rains had prevailed. Tanganyika, after all, is but a large cistern, and must at that time have been as full as it could be. The outlet through a mountain gorge therefore ought, according to all physical probability, to have been what was called in Scotland "in spate," with a great rush of water out of it. Instead of this, Lieut. Cameron found it choked up with weeds and grasses, which he could not cut his way through. When Livingstone, in a burning state of fever, passed along that part, the Arabs anchored their canoes every night in one of the numerous bays, which in many cases extended 4 or 5 miles in amongst the mountains. So far Dr. Livingstone's account tallied with that of Lieut. Cameron, but the 1000 feet fall was a great difficulty to Livingstone. He knew, as far as he could know from native report, that a river did flow from Lake Tanganyika through the mountains, and eventually found its way into the Lualaba. It was a long time before he found his way out of the difficulty of the great difference of level; but he was at last told by the natives that the river, after leaving the lake, fell over cataracts. This would solve the difficulty connected with the altitudes. With respect to the Lukuga River, it should be remembered that unfortunately the same or nearly the same name was applied to many streams. Livingstone made one large river flow in on the lake's western shore, and that was the nearest river to the point where Cameron had found his Lukuga. Livingstone marked it the Lofuku River, and placed it to the south of the Logumba, which flowed into Tanganyika, he was as certain as he could be about anything. There was also a river Loñgumba, and the similarity of the names tended to beget some confusion. With regard to the name Ugarowwa, it should be remembered that the " $R$ " and the " $L$ " in all these names are interchangeable, and Chumah and Susi both stated that the Lualaba when it gets to the North is called the Ugalowwa. It might therefore, after all, be the Lualaba into which Cameron's river runs. 'There was still a great deal to be learned on this question, and it was a very fortunate thing that a young officer, full of zeal, in good health, and thinking nothing of hardships, was out there engaged in solving the problem.

\section{Report of the Proceedings of the Livingstone Congo Expedition. By Lieut. W. G. Grandy, R.N., Commander of the Expedition.}

The Presinent, in introducing Lieutenant Grandy, said the Meeting would remember that, when it was supposed that Dr. Livingstone must be in great distress in Central Africa, a relief fund was instituted by some of his friends for the purpose of affording him assistance from the East Coast; while one of Livingstone's old friends, Mr. James Young, of Kelly, came forward, and, in the most munificent manner, offered to defray the whole expenses of an expedition which should proceed up the Congo from the West Coast, and endeavour to meet and afford relief to Livingstone, if he sbould return to his 
native country by that route. Lieutenant Grandy was sent out, and all the expenses that he had incurred had been met by Mr. Young to the amount of over $3000 l$. Lieutenant Grandy did all that a man could do under the circumstances, but he met with the greatest possible difficulties, and ultimately was obliged to give up all hope of entering the country to the south of the Congo. He then crossed over to the north side, and with better hopes of success, and was on the point of proceeding into the interior, having made his arrangements for doing so, when he received the letters recalling him. When the positive news of Livingstone's death arrived, of course the Society could not expect Mr. Young to continue to defray the expenses of the expedition for purely geographical purposes. Lieutenant Grandy had gone over a good deal of new country, and the results of his observations were of very great value. He might have had to complain of one or two Portuguese officers with whom he came in contact, but, on the other hand, he received from the Portuguese Agent at Bembe great assistance.

Lieut. Grandy then read his Report as follows:-

The Expedition left Liverpool on the E0th of November, 1872, and, calling at Sierra Leone to procure men, proceeded to St. Paul de Loanda, where the outfit was purchased; and finding on inquiry that Ambriz would be the best place to obtain carriers for the interior, we started for that port on the 15th of February, 1873; and, after considerable difficulty in procuring the requisite number, left on the 12th of March; and passing round the east side of the swamp proceeded in a north-easterly direction through Cola village and across the Loge River, which at the ferry is 35 yards wide and 3 fathoms deep midchannel, with a current going to the westward of $1 \frac{3}{4}$ knot an hour. On the left bank for some distance above and below the ferry are large plantations of bananas and sugarcane, the latter being used largely in making rum; the factory is on the right bank of the river, and is owned by a Portuguese named Jacinto: here the rum is manufactured, and I am told the demand is so great that it is necessary to give an order twelve months in advance. Crossing the river, we proceeded through some low swampy grourd with high grass towards the village of Kingombo; and as I did not deem it prudent to remain in such a swampy locality, we passed through the town, and climbing. a hill established our camp on the crest of it; here we were visited by the chief of the town, who dashed us with a small pig, and was apparently anxious to explain a great deal about himself and family, and their importance, but fortunately was too drunk to do so, and we were thankful to get quickly rid of him, with a promise of seeing him on the morrow. On the morning of the 13th, having passed an exceedingly unpleasant night (almost eaten by mosquitos, which drove me out of the tent several times, in spite of the heavy rain which came down nearly all night long), the capata came and said the carriers were perished with wet and cold, and anxious to 
proceed; and, as the weather looked promising, and I did not feel disposed to endure another night of torment, I made arrangements for a start: got away shortly after nine o'clock, and proceeded in a nearly north-easterly direction, and camped for the night at Muxixe, just outside the village. We struck camp very early on the following morning (the 14th), and after $4 \frac{1}{2}$ miles' march through high grass we reached a small village, with a remarkable cone-shaped hill on the left covered with trees. The water here was so bad I would not allow the men to drink it, and an hour's farther march brought us to the village of Zunga, pleasantly situated in a clump of trees; very good water can be found close to it : in $1 \frac{1}{2}$ hour more we arrived at the village of Wibisi, and pitched our camp close to a good stream under a large tree, which afforded an ample shade from the sun. The country is already improving in appearance (today we passed through some very pretty park-land with large grassy plains), and getting more elevated and ridgy; soil principally sand, with some stray boulders of granite. The village is on the rising ground on the opposite side of the stream. We found everything exorbitantly dear here, and therefore purchased only what was absolutely necessary. We are not yet far enough from the coast to excite much curiosity in the minds of the natives.

On the morning of the 15 th we started at 4.10 o'clock, having a good moon to guide us, and arrived at Vakage shortly after 6 , where we halted a short time; then on in an easterly direction, through high grass, and crossing three small streams, arrived at the village of Lamboo. We were all much done up from the excessive heat of the sun and the long march. We found good water here, but provisions were both scarce and dear, owing to the Portuguese having burnt the village about six months previously.

We remained here Sunday (16th) to rest the carriers; and early in the morning (7 o'clock) a heavy tornado from the north-west passed over; fortunately our tents were well pitched under trees, or they would have stood a poor chance.

Started on the 17 th at 4.30 A.M., through long grass saturated with dew, which was anything but pleasant, and, descending, forded the River Kidilo, which was waist-deep. Passed by a small village, where we found some carriers, and two hours' march brought us to another stream: here we noticed a palm-tree, the first we have seen since leaving the coast. Morning fine and cool; wind easterly; barometer in valley, $29^{\circ} 45^{\prime}$. After fording the Kala River the palmtrees became more abundant. We had a great deal of river-work to-day, besides some disagreeable swamps to cross, and were very thankful to reach Quiballa : here, owing to the carriers loitering, 
I was obliged to remain three hours in my wet clothes, fortunately without any ill effects. This is the first large village we have seen : it numbers about 400 souls, and is pleasantly situated on a rising ground, and well surrounded by trees. There are large gardens and extensive farms in the neighbourhood: ground-nuts, cassava, bananas, limes, sugar-cane, and guavas, chilies, \&c., are produced here in abundance; the rubber-vine also grows plentifully. The huts are well built, wattle and daub, with thatched roofs, and the town is kept tolerably clean. There is a hut set apart for the accommodation of strangers. I exchanged some small presents with the chief, who is very old, and very partial to the white man's rum, if not to the white man.

I delayed here one day to rest the carriers and give those behind an opportunity of overtaking us, and started at daylight on the morning of the 19th; the carriers would not leave earlier on account of the first portion of the road being very stony and precipitous. We crossed the Quiballa River twice whilst making for the head of the valley, and that finished with the rivers for the day. We had some stiff climbing to reach the crest of the hill, on which is the village of Matooka. The deep valleys are all under cultivation. Passing through the villages of Kibella and Gungongo, and along a tolerably good road, we arrived at the village of Kanangwala, where we camped for the night. The house of the chief was built after the manner of the Portuguese, with doors and windows, and whitewashed, giving it a very neat appearance. Just after dark, the chief commanded silence in the village, and then, in a rich, clear voice, told his people and the strangers-a good many of whom were in the town-that there was a white man arrived with a large quantity of goods, and that he hoped no one would be guilty of thieving, which would give his town a bad name: to which they shouted in chorus that they would not. I dashed him before leaving for his honest intentions. We saw a woman spinning native cotton : here the plant grows abundantly.

On the morning of the 20 th we struck the camp at 3.30 , and for the first mile had a very uncomfortable walk through long wet grass; then about 2 miles to the head of a valley. Over the crest of the hill, down an incline, and breasting another hill, we saw to our left, perched in a nook, the village of Tomboko. Descending the hill in a thick fog we arrived at a breakfast-place, where native women, in anticipation of the carriers arriving, were busily preparing foo-foo and bean-soup. From this point the road was nearly level, with high grass. At 10 o'clock arrived at the village of 
Kimalenso. We found provisions much cheaper here, and could obtain guavas, pumpkins, tomatos, beans, fowls, and onions.

Friday, 21st. Started at 4 o'clock, with a good moon to light us on the road, which was good and very tolerably level. At 5.30 we came to a nasty piece of swamp, and then, gradually ascending in an easterly direction, passed round a hill, and from the top of a neighbouring one obtained our first view of Bembe Hills : descending, we passed through a swamp, waist-deep and 100 yards across, and then on through high grass till near the Muchinga River, where we halted three-quarters of an hour. At 10 o'clock we crossed the Loofoozi River, 40 yards broad, waist-deep, with a rapid stream running at the ford. After crossing, pushed up through a piece of jungle and wood that skirts the river, waded through a small swamp, and, ascending a hill through long grass, saw at the bottom, in a clump of trees, the village of Quilumbo Cambembe, where we slept the night.

We found some of our cargoes that had been sent in advance in this town, so added the carriers to our party, and started on the morning of the 22nd, at 4.30 , en route for Bembe. We had four streams to cross to-day, but fortunately all were bridged. Aurived at Luchinga, we halted for an hour. This village is planted in the centre of a grove, with a river of clear and beautifully cool water passing it. As the sky looked threatening I hurried the carriers on, and after an hour's march, over hill and dale, through long grass, plainly espied the whitewashed buildings and fort of Bembe 3 miles distant. At noon we crossed the Luqueia River by a bridge nearly finished; it is planked, and by far the best we have seen. We were very glad to be able to make use of it, otherwise we must have rafted across or swam the river, as it is deep and broad.

We reached the citadel of Bembe on the 22ud of March, after a breather up the hill, which is very steep, and were very kindly received by the Chefe, who housed the men comfortably in a portion of the barracks, and gave a lock-up store for our cargoes. The last carriers arrived at 3 o'clock, and shortly after the rain came down in torrents, with much thunder and lightning, which lasted till midnight. This is the season for heavy rains The finest months at Bembe are May, June, July, and part of August, when the weather is nice and cool. The latter part of Augnst and the month of September are also considered fine: in October and November there is plenty of rain; in December, January, and February light rains; March and April are the big rains. Bembe 
is the most advanced post of the Portuguese, and at the same time a very important one, as commanding the roads to and from the interior. The fort is in a very bad state of repair, and there was a strong rumour that the Portuguese intended abandoning it. There are four markets held on consecutive days near Bembe; the first is called Candoo, the second Conzo, third Kangue, and the fourth Sonha.

Tuesday, 25th March.-Paid a visit to-day to the copper-mines. There seems still to be a considerable amount of ore there : formerly they had an English manager here and every requisite in machinery; but the manager died, the Company got into difficulties, and the whole plant was eventually destroyed by fire. There is a Chefe at Encoge, 3 days south of this, through whom communication is kept up with Loanda. The place produces large quantities of good quality coffee, and fine sheep may also be obtained, but the climate, from the greater quantity of rain that falls, is much more unhealthy. At Zombo, which lies about 7 days' journey from this, good cattle are obtained for cloth: it produces also coffee, india-rubber, tobacco, palm-oil, \&c., and is considered a large place. Sierra Bembe, which is a remarkable mountain, and round the base of which passes the Luqueia River, is 1695 yards from the fort. I took a boiling-point on its summit, which gave a mean reading of $208^{\circ} 1^{\prime}$; barumeter, $28^{\circ} 16^{\prime}$; thermometer at commencement, $78^{\circ}$; at finish $82^{\circ}$.

Thursday, 3rd April.-Having vainly endeavoured to procure carriers from the different villages round Bembe, who, one and all, refused to go even when the Chefe exerted his authority to assist us, saying, there was too much water and too much long grass on the road, we determined to send to the King of Congo for men, and accordingly dispatched the interpreter, one soldier, and a capata, with letters from the Chefe, and ourselves, and a good present.

Wednesday, 9th.-Paid a visit to the caves, which are in the same valley as the mines; but a mile further to the southeastward they are very interesting, and the rocks from which they have been scooped form a strange feature amongst the surrounding soil of slate and shale, being composed entirely of limestone ; the entrance to the first cave is by a low narrow passage, and having arrived at the end, you enter a circular vaulted chamber about 35 feet in diameter and 40 feet high; beyond this again is another chamber nearly 60 feet in height, and also circular; in these caves it is said the natives deposited the copper ore they collected at the mines, before the Portuguese took possession. Passing round to the right, 
after emerging from the first two chambers, you enter a second cave of greater extent but not so regular in shape; the roof gradually sloping to the ground. We found some few specimens of malachite in the caves.

Sunday, 20th.-At 4 o'clock, our party returned from Congo, bringing with them 66 carriers; they were six days coming back, and report the roads very bad; they brought several letters for the Chefe and one for us, expressing a wish that we would come speedily, and enumerating a list of articles to bring as presents.

Thursday, 24th.-Started the 66 carriers with an escort of seven men; we were both down so badly with fever that had not the Chefe kindly assisted us in arranging matters we could not have got them away to-day; they have promised to send us more men back from the towns as they proceed.

Wednesday, 30th.-Having succeeded in collecting 30 more carriers, started my brother with six men as escort for Congo on the morning of the 1st of May, and accompanied them as far as the River Loozi, and superintended the crossing; this river is generally insignificant, but owing to the heavy rains had overflowed its banks, and was nearly 90 yards across; there was considerable difficulty in getting the cargoes over, the natives being afraid, as the river in the centre was chin-deep, and but for our own men they must have encamped for the night.

Sunday, 4th May.-There was a conference held to-day with the Soba of Matatu about taking charge and care of the fortress of. Bembe when evacuated by the Portuguese; and it was partly agreed that on consideration of his doing so he was to receive 200,000 beads per month, and the Soba of Bonde 60,000 beads. I cannot help thinking it a great mistake to give up possession of a place which is the key to the interior; and a day will yet come when they will repent having relinquished a position that cost Portugal so many lives and so much money to obtain. The moment the troops leave, the road to the coast will be stopped, and Ambriz will suffer a great loss of trade.

Wednesday, 7 th.-The requisite number of carriers arrived today, and I had fever, unfortunately, too bad to allow of moving, so did not make a start until 9 o'clock on the morning of the 8th. I was exceedingly sorry at parting with the Chefe, who in his kindness and attention to our men and selves has been almost as a brother; he pressed on me from his small store some rice, wine, bread, \&c., and accompanied me to the first village, where he embraced me, and wished me Godspeed and good fortune. Our men, I am glad to state, fell in of their own free will, and one of them, 
acting as spokesman for the rest, thanked the Chefe for his great kindness to them; he seemed much moved at their expressions of gratitude, and said he had never known black men thankful before. 'Two hours' march north brought us to the Loozi River, which fortunately had resumed its normal condition, being only 9 feet across and 4 feet deep, the stream going to the westward. Crossing the river we passed up through the village and proceeded in a northerly direction for Miembe, where we slept at night; starting at seven the following morning, twenty minutes' walk brought us to the cross roads, one of which leads to Zombo. Here, stuck on poles, were the heads of two men who had a few days previously suffered torture and death for theft; their calcined bones were in the grass and their clothes hung on the bushes; the heads, on which the wool and flesh still remained, presented a very ghastly spectacle. The day's march was principally through long grass with some climbing, the road tolerably good: we descended to the Lafoozi River, and crossed it by a bridge that had just been completed above the rapids; I paid a toll of 12,000 beads for the crossing of the whole party. We were detained here $1 \frac{1}{2}$ hour getting the donkeys across and repairing their loads. The men enjoyed a good bath, and astonished the natives with diving and swimming. At 1 o'clock we arrived at Loofoosa, where, as the capatas and carriers belonged to the village, we halted for the night. It is the largest town we have seen since leaving Ambriz, and is tolerably well kept; it musters about 120 guns. Palm-trees are very abundant, and there is good water; but provisions, especially fowls and goats, are dear. The people are quiet and civil. They were very much frightened at first at the donkeys, and did not know what to make of them; but when they saw them quietly grazing and taking food from our men their fear yielded to curiosity, and they crowded round to examine them. The men and women of this town are tall and well made. The chief paid me a visit after dinner, and I explained to him the object of our journey; how Dr. Livingstone had been labouring for more than thirty years, giving up home, country, and friends, and devoting his life to their benefit, and eradicating the curse of their country-slavery. I explained to him the manufacture and use of india-rubber and candles; and that his country supplied the materials, by the cultivation of which and sale to the white man, he would greatly prosper. He seemed perfectly to understand and appreciate the necessity, but replied, that unfortunately be was now very old, and his people were too indolent to cultivate more ground than their wants required.

Saturday, 10th.-We were away this morning by seven, being 
anxious to cross the Breeze River, which is a large one, before night. For the first hour the road was good though stony, and ascending the hill, we saw the river and direction of the ferry. (An extensive range of mountains commence near Lafoosa, extending in a north-westerly and south-easterly direction, the most prominent peak of which is called Engombo.) Having crossed the Kindamba swamp we proceeded over a stony plain in a northerly direction to the Tende River, which was happily bridged. Crossing it we ascended and passed over the range down through very high grass to the village of Diage, where we had some difficulty with the carriers, who refused to proceed any further that day; and it was only by the application of something more than moral persnasion that they were induced to continue the route. One hour brought us to the Breeze River, the passage of which, owing to its swollen state and strong current, with the unpleasant addition of a tornado, occupied five hours; and but for the courage and skill exhibited by our men, one canoe would have been lost. By 9 P.M. everything, including the donkeys, had crossed; and breasting a very steep hill we were glad to reach the little village of Kingo, wet through, and very tired and hungry. It was too late and too dark to attempt to pitch tents, so we were all huddled together in a semi-roofed hut, through which the rain percolated freely. We made some tea with muddy water; and with that and a few ground-nuts for our dinner, composed ourselves to obtain what sleep might be possible under such circumstances.

We were astir at daylight the following morning (Sunday, the 11th), having passed a miserable night in wet clothes, with empty stomachs, and a plentiful supply of rain; and having changed and dried our traps, moved to the village of Makorko in search of something to eat, which after $\frac{3}{4}$ hour's march we reached, and found provisions cheap. Being Sunday we remained here the day to rest the men after the fatigue and discomfort of yesterday. I was told by the chief of this village that there are hippopotami in the Breeze River, but the natives have too much fear of them either to attempt to spear or shoot them. This village is frequently visited by leopards, which destroy a great number of hogs. I made an ambush and watched several hours, but without any result, until driven to shelter by the heavy rain.

Monday, 12th.-At 7 A.м. started; morning fine with clear sky, but foggy in the valleys and round the trees; by 8.30 we had completed crossing the Buila River, which from the late heavy rains had overflowed its banks and become a swamp of 300 yards, in some places shoulder-deep. After $1_{2}^{\frac{1}{2}}$ hour's struggle through high grass 
we crossed it again, being obliged to fell trees to bridge it, and $1 \frac{1}{2}$ hour's further journey brought us to the village of Matampe, where we halted for half an hour, to enable the carriers and men to purchase provisions, which are not procurable at the next village. At this place we were to have met with opposition; but, having previously sent word what course of action I should take if molested while travelling on a peaceful errand through the country, all passed off quietly, although about 100 natives put in an appearance with guns. Shortly after leaving the village we passed the Buila again. The donkeys give a great deal of trouble swimming them across rivers and loading and unloading them: I am afraid they will nerer be of much service to us. After crossing two pieces of swamp, arrived at the village of Pango, where we passed the night. A man was brought to us here, who stated he had seen the white man we were looking for six months ago at Sundi. This we considered morally impossible, but hoped we might get some information from him. He stated Sundi to be twenty days' march from Congo, or ten days by water, and that he had been sent there by the chief of this village for teeth; when pressed for more definite information, he said we should meet men at Congo who would tell us all we wanted to know.

May 13th.-We had a good deal of rain, which lasted till 3 o'clock in the morning, when a thick fog came on. The grass was very wet and uncomfortable for marching: $2 \frac{1}{2}$ hours' journey completed the crossing of Manzonje Swamp, which being broad and deep made it a difficult matter to get the donkeys across. We then came to the Malunda River, which, owing to the velocity of the current, occupied an hour in crossing, and proceeded to the village of Lovoo, where we breakfasted; and after wading through the Mobooto Swamp were very glad to reach the village of Kinsanga, for the weather looked threatening, and it was thundering to the eastward : it passed over us in the shape of a tornado three hours afterwards.

May $14 t h$.-We were on the move early (had much rain during the night, which makes the road bad for travelling), and passing two swamps and a small river, arrived at the village of Tonkila, where we halted for breakfast and to prepare for the water ahead. We crossed successively a small swamp and river, then the Embomk Swamp, which ranges from knee to breast deep, and crowning the hill, arrived at the village of $\mathrm{Ma}$ Lomboo, through it to the Musangany Swamp, and north-north-east to the Koko River ; passing round a bend of which we arrived at the village of Maunza, and slept the night. The town belongs to Congo, so we were well taken 
care of, and, having a comfortable hut to sleep in, did not mind the rain, which came down in torrents.

Started at 6.30 on the 15 th, and crossing the Koko River arrived at Kangyakewa, where there is a large and remarkable tree with the initial letter "F. 58 " cut on the bark: we put "G. 73 " beside it. Passing on, with the river on our left, which is very sinuous and full of obstructions, we entered the village of Kimpango, and halted for breakfast; then proceeded north-north-west and followed the Koko River for about half-a-mile, crossing a small stream that joins it, ascended a hill, and saw the Congo Plateau 6 miles ahead. The ground here was cultivated, corn, sugar-cane, beans, \&c., growing plentifully. Anxious to complete our journey, we pushed on, and passing through the village of Kimalo down to the valley, arrived at and crossed the Luaji River, which had considerably overflowed its banks and rendered the passage of it difficult. One hour's march brought us to the village of Ovoonda, where we were met by a number of King Totola's people, and in company with them, after half-an-hour's journey, reached Congo and had an audience, delivered to the King some letters, \&c., and then begged him to excuse us a short time while we changed our wet clothes. Returning, we were received with great state: the old King sitting on a chair under a huge state umbrella, habited in the uniform of a Portuguese Lieutenant, and surrounded by his sons and principal chiefs. Chairs were placed for our accommodation, and rugs and carpets spread in profusion; salutations were exchanged amid a flourish of trumpets, tom-toms, \&c. He expressed his great joy at being visited by Englishmen, requested to be allowed to salute us with 100 guns, and hoped that we should remain a long time with him, and consider his town as our home in that part of the world, and that many more would follow us, for he was very fond of the white man. After an introduction and general shaking of hands with all the principal chiefs, we were allowed, as it was getting dark, to retire and attend to ourselves, promising to come early in the morning with the presents.

Friday, 16th.-While busy selecting cloths for the King, he sent to ask us to shoot a bullock for ourselves and men, and refused to accept more than a hind-quarter for himself. About noon we marched the men to his place with the presents, with which he was very much pleased, saying no white man had ever so honoured him. We considered it necessary to give as much as possibly could be afforded, in order to make a good friend of him, he being the most important person in the country, and whose influence would materially affect our future prospects. In the afternoon he paid 
us a visit, and we broached the subject of the carriers; difficulties immediately presented themselves - bad state of the roads, quantity of water, danger of being fired upon, price, \&c. We managed to dispose of his objections one by one; and it was eventually settled that two of his sons were to busy themselves in obtaining carriers, and he would send a messenger to the King ahead to clear the road for us. We saluted him this afternoon with six salvoes, at which he was very pleased; and sent again to say that no white man had ever treated him so well as we had done, and that he would always do his best for any one who might in future visit him. Congo, or the San Salvador of the Portuguese, is situated on an elevated plateau 1500 feet above the sea-level; it has formerly been an extensive fortified city, surrounded by a loop-holed wall averaging 15 feet in height and 3 feet in thickness, portions of which are still standing. There are also the ruins of a large church or cathedral at the north-west portion of the town. The Portuguese held military occupation for some years, but abandoned it in 1870, and their forts and barracks are now ruins completely overgrown with rank grass and shrubs. The town is supplied with water from a beautiful spring which issues in three small streams from the clay soil half-way down the plateau on the east side of the town. 'There are very few trees near the town; bananas, plantains, and fowls are plentiful and cheap, and the farms of beans, cassava, and groundnuts are well kept. There are three markets weekly held near the town. The Congoese are great snuff-takers and smokers, are well clothed, and a great many speak Portuguese; they are darkcoloured and of average height, but not muscular; indifferently armed with flint-muskets and knives, and very fond of hunting; they make free use of the knife in their quarrels, not using it as a dagger, but giving long sweeping cuts across the back, breast, and stomach. They are habitually lazy. The women are decently clothed, modest, virtuous, and exceedingly industrious. They tend the farms, look after the house, and cook the meals; whilst the man sits quietly down and smokes his pipe. Polygamy is general in the country, and a man is accounted rich according to the number of his wives, who, as soon as married, select a piece of ground which they industriously farm, the produce being sold at the markets for beads, cloth, \&c. The King of Congo has two nephews, and, by the laws of the country, one of them, who shall be the choice of the people, succeeds to the throne: failing a nephew, the people elect a king themselves. The sons of the king do not in any way participate, nor are they entitled to any of his property; but during his lifetime he can appoint them to chiefships of towns

VOL. XIX. 
in his kingdom as vacancies occur. The King of Congo commands the road from the interior to the coast, and levies contributions on all "chiboukas" of ivory. He was once a very powerful chief, and, being supported by the Portuguese, was much respected; but since they withdrew from Congo he has been gradually sinking to the level of other chiefs; and although he keeps up an outward show of authority he has very little power.

May 18th.-Had a consultation this morning with two old hunters and the King's son about the different roads, and am convinced that the one to Sundi is the shortest and best. They call it nine days' journey without loads, or twelve days with loads, and say the travelling is good, and that silver and copper are found there.

The Zombo Route, though longer, would have suited us, as there we could have joined ourselves to one of the large chiboukas which ge annually towards the Manueyma country to purchase ivory (they number from 500 to 800 strong, and are all armed); but unfortunately there is a big palaver between the Congo and Zombo people at present, about the murder of a man. And again, at this time of the year, there is a great deal of water; in one day's journey alone we should have to cross seven unbridged streams; and as we have already between Ambriz and this had plenty of the element which has been productive of fevers, colds, and rheumatisms, it would not only be more expeditious but more healthy to take the direct road. The rains still continuing are a great evil to us, as the grass burning cannot commence, and it is some 8 or 10 feet high; and the paths are so overgrown that you have to push your way through (which is very laborious work), and get thoroughly soaked into the bargain. They say there is plenty of game on the Sundi road, but, owing to the long grass, very difficult to find.

Monday, 19th May.-There is still great trouble about the carriers; they keep putting us off from day to day with endless excuses, evidently meaning to detain us, and get as much as possible out of us. Went to the King, after breakfast, and reminded him of his promise to speedily procure carriers for us. He replied it was true, and that he was doing his best to make the road clear; and would on the morrow despatch his most trustworthy son to the King of Makouta, if we would pay his expenses and send some presents : to this, of course, we readily agreed, and offered to send two of our interpreters with his messenger; but he said "No, it was better he should go alone." Had to listen to another " canard " to-day about a white man, who was in the interior trying to come to the coast, and that people took him ivory and other things to buy, but he 
replied that he did not trade. The last accounts of him were that he had built himself a. town, had fifty soldiers with him, and was making farms to grow produce to sell and pay his way to the sea. They say that he is only one month from this on the right bank of the Quango River. This story, with slight variations, has been repeated by several, who declared they had been close to the place; but when asked to describe the man, they replied, not themselves, but their masters had seen him. There are no travellers in this part of the country; for when men have been brought before us, said to come a long way from the interior, and we have produced the map, and questioned them about the different places, we have invariably found them to know less of their country than we did, and that their long journeys were pure fiction. Small-pox is getting very prevalent, and fatal cases occur daily. How much I regret we have no vaccine matter with us; the natives do not seem to understand the treatment of the disease, or the precautions to be taken to prevent infection, and I am afraid it will make sad havoc amongst them. Thank goodness, all our men have been vaccinated. I went to the King and explained what measures he should take to arrest the spread of the disease, and he has promised to adopt them. He told me his eldest son, who was to have accompanied us, was taken ill with it to-day.

Sunday, 1 st June.-We have had no rain since the 28th, and may fairly suppose that the fine season has set in, for the heavy morning fogs which herald its approach have already commenced. We are getting very impatient at this continued delay, and have not ceased urging upon the King the importance of an early move. To-day his son returned from Makouta; but he has to tell his story to the King before we are allowed to hear what he has done.

Monday, 2nd June.-The King came round to see us this morning, and we were at him again about the carriers. He says he is very angry with the son, who went to Makouta, for delaying so long on the road, and not carrying out his instructions properly. We made him give his statement of proceedings in the presence of his father; which was to the effect that the King of Makouta had received our presents, and was very glad to hear that Englishmen were coming to his country; that he would come himself to hear all about us from the King, and would be here in five days, bringing carriers with him.

Saturday, 7th June.-Our patience has been sorely tried with unsatisfactory excuses and delays in procuring the carriers, so had a long and serious talk with the King about his conduct in the matter. He would insist that the road to Sundi was very dan- 
gerous, and that the people would fire on us all the way, and not give us time to eat or sleep. After two hours' palaver, he at last promised he would furnish carriers to Makouta; but he would send messengers to Bembe and Loanda, to say that we would go where we were sure to be shot, and they were not to blame him for what might happen to us.

Friday, 20th June.-After innumerable delays and vexations enough to try the spirit of any Job, we have, at length, succeeded in collecting and paying the carriers, and managed at 5 P.M. to get away from Congo; and after an easy march, in a northerly direction, arrived at the small village of Kikembo. I began to fear we never should get out of Congo: the disaffected people were constantly bringing in reports that chiefs whose towns we were to pass had sent word that they intended to fire upon and exterminate the whole party, and therefore carriers had better not come with us. These, and like stories, which it would be tedious to repeat, lost us a whole month of the best season of the year. We insisted upon the King punishing one man whom we had caught setting his countrymen against us, and preventing the carriers from offering their services. We went before leaving, to wish the King good-bye, and make him a parting present. He was very thankful; and begged us to think that he was our great friend, that his heart was right, towards us, \&c., that he had done his best to get us forward; but his people kept the carriers back by circulating lies about the daugers of the road; that we would eat them when we got them far away, and never allow any of them to return to their country.

Saturday, 21st June.-Did not get away till late, owing to some of the carriers having returned to Congo for the night. Half an hour brought us to a gorge, through which we passed, and down the high level of a valley, hills nearest on the right hand, with outcrop of granite. We can plainly see that this would have been a very bad road three weeks earlier, the valley would have been a swamp. The grass is similar to that we met with from Bembe to Congo, where you pull your hat well down over your eyes and take a header, emerging only when you arrive at your destination; nothing to be seen above the wall of grass but the heavens, and often not even that. The sun was very hot to-day; and after an hour's slow travelling, the carriers came to a halt at the head of the valley. They are a miserable lot, stopping every five or six minutes. After many delays we reached the village of Kintano, where we halted for the night; had a visit and present from the chief, and took the opportunity to explain all about ourselves and our mission, and managed to do away with the bad impression 
existing in their minds about us. We were well pleased, for this was one of the towns named where we should meet with opposition; and instead, we have been well received, the carriers have taken heart, and now talk very courageously.

Sunday, 22nd June.-Started at 6.30, and an hour's journey brought us to the Loanza Swamp, which occupied an hour in crossing, owing to the difficulties of getting the donkeys through the slush and mud. Passing up to and through Banza Loanza, in five minutes we reached another swamp; crossing which we arrived at the village, where we found the chief, who, by special desire of the carriers, had been sent ahead with presents to clear the road, and was to have met us at Makouta.

We were detained here 45 minutes, while I explained to the carriers and town-people the rascality of the old man. Forty minutes' further march, and we reached the Pambala Swamp, which was, happily, partly bridged. Crossing this, we proceeded to the village of Luquakwa, which $I$ was very thankful to reach, having been in a hot fever for 2 hours. After a rest and refreshment, again took the road, and after 2 miles' march, arrived at and crossed the Nyangetta Swamp, and, breasting the hill, entered the village of same name, where we halted for the night. Resuming our march the following morning, a short journey in a north-easterly direction, over hill and dale, brought us to Banza Tanda, a town of some consequence, situated on the crest of a hill, surrounded by trees. Here the natives turned out with their guns (about 130), thinking we had come to take and burn their town; but a short explanation convinced them our visit was a friendly one. The country is improving in appearance; clumps of trees are more frequently met with, and the palm is abundant. The people of this town trade to Vokay and Noki, with ground-nuts and palm-oil. We found provisions rather dear. Detained here one day with bad fever.

25th.-We continued in a north-easterly direction for Kilembella (the road good with less grass, but a great deal of climbing), which we reached in a couple of hours. I received a very extraordinary message from the King of this town, asking me to order my men to wear their trowsers, as they did not consider the handkerchiefs, which the men usually wore on the march, sufficient clothing. I could not help smiling at this excess of modesty, but, nevertheless, satisfied his whim. We were kept waiting an hour before admitted to an audience, during which time it was evident, by the King's appearance and manner, his people had been priming him with palm-wine. He was a fine, tall, muscular-looking man, but being 
very drunk, was quite the savage, dancing and capering round us like a big baboon, and flourishing a rusty old sword, declared that no man was to move out of his town under penalty of death. Foreseeing the effect this was likely to have on the carriers, we endeavoured to arrange a large present for him and proceed; but the threat had already taken effect, and the carriers were bolting from the town en masse, and by 8 P.M. not one was to be found. Here was a dilemma. These men had been paid to take us to Makouta. King Totola had made them a long speech before leaving Congo, urging them to fulfil their contract, and sending his own secretary and two principal chiefs on purpose to give them confidence, and yet by a few words from the mouth of a half-drunken man they had melted away. One chief, who volunteered to accompany us from Kikembo, alone remained faithful; but he was forcibly dragged away by his own people. Of course, we were very angry at such conduct on the part of the King, and the following morning early, when we thought he was sure to be sober, we sent for him and explained how shamefully he had behaved. But expostulations were useless; he declared it was all a mistake; that he had been told the carriers were to leave us here-this being the limit of the King of Congo's territory - and that his people were quite capable of taking us to Makouta. Finding we were trapped, the best plan was to put a good face on matters, and tell him that as we were anxious to proceed, if he would collect the carriers without delay, we would give him a handsome present. Kilembella is a considerable town on the borders of Congo (this new kingdom extends as far as the Quilo River, when you come upon the Makouta territory). It is situated on the top of a hill, with water round. There are large groves of palms, and ground-nut farms, but no corn, plantains, or bananas, which is rather remarkable. Two good markets near, which are well supplied. There are two varieties of bean - the ground (creeping) and tree-bean; the latter is sometimes left for two years before cut down. This place could produce a large quantity of palm-oil annually. We explained this matter to the King, and gave him a candle, telling him that was made from the stearine, and that if he chose to manufacture the oil and send it to the English factories, he would obtain a good price. He replied that he had no idea they would purchase it, but that he would now give bis attention to it, and send 40 loads to Boma as a trial; he is also going to try and grow corn and bananas.

Saw several green pigeons and two grey parrots : cardinal birds have disappeared; Congo and Bembe abound with them. The grass is beginning to get a brown tint, and ought, I should think, 
soon to be burnt. They say after passing Makouta it is less high and less plentiful; we are thankful for that news. Makouta, from all accounts, is the land of plenty; this certainly is not. One would hardly credit we could have travelled from Ambriz to this without killing some game. The houses of Kilembella are badly kept, and the yards never swept. Some women hide the bosom, others not; but all are decently clad. The country round is so broken by hills and valleys, that it would be a matter of considerable difficulty to find a level of 6 or 7 acres. Villages are very numerous between Congo and this on both sides of the road.

It was not until the 5th of July that we were enabled to satisfactorily arrange the number of carriers, their payment and presents to the King and chiefs. To prevent, if possible, being again deserted by the carriers, we subsidised the King of Kilembella, and brought him with us, also his secretary and his son.

One hour's slow travelling in a northerly direction is the village of Keweve, the approach to which is through the finest bit of wood we have seen; the trees large, lofty, and abundant, affording a grateful shade. The village rests on a hill, is large, and well built, and very clean; streets regular, and swept; in fact, the place had quite an air of civilisation about it. One hour and a half farther journey and we were at Mokumbo; here reside the family of the King of Kilembella. This village was also well kept, and there were plenty of fine sheep, also goats, pigeons, and fowls. Passing through the village, and emerging from the trees, we saw to our right the mountain range of Zombo, with a plain some 12 miles in extent intervening. The day was very warm, and the carriers were a good deal done up when we reached the village of Onza; which, although belonging to our King, refused at first to allow us to remain (some malicious natives having spread reports calculated to deter us); but after a long palaver, and taking into consideration that the sun had already set, they allowed us to halt. They cultivate large quantities of corn (maize) around this town, and we noticed fields of it near the villages we passed to-day.

July 6th.-We reached the town of Moila, the chief of which is a son of our King; the men and women took to the bush on our arrival, and it was some time before they could be coaxed back. The following morning the chief paid us a visit, and made a present of a sheep. We remained the day, as there was a market held ahead, and the chiefs were afraid that the drunken men would be firing on the carriers. They held a grand "batook" in the town, which lasted till past midnight; these country people are very fond of dancing, at least the male portion, and think nothing 
of keeping it up all night when the moon will give them light enough.

Leaving Moila on the 8th of July, we arrived at the village of Mokanda, after crossing a swamp and two rivers; we made but a short march, but the carriers refused, in spite of the King's commands, to proceed any farther. We observed recent tracks of elephants on the road, but the grass is too long to attempt to follow them; after we arranged everything for the night, went to one of their drinking-places and watched for some hours, but with no result. The carriers are beginning to get uneasy, and I hear it is their intention to leave us at Vindu to-morrow. Started early in the morning (9th), and passing through the village of Lovoo, we hastened on to Vindu, to be ahead of the carriers, and pack the loads as they arrived to prevent any plundering. They kept us waiting for an hour outside the town, which is very extensive and well built, situated in the middle of a large clump of trees. Before the chief's house is a large square, where a "batook" was going on. Could not have an audience with the chief until our own King arrived, and he did not put in an appearance until very late, so all exchange of presents had to be settled in the morning. Went out to look for elephants and caught fever.

On the morning of the 11th started for Banza Umputa; had a good deal of high grass to push our way through to-day; but, fortunately, only one small river to cross; arrived in good time at the town. Here we heard that it was the intention of the carriers to leave, notwithstanding the extra payment we had made them at Vindu.

July 12th.-During the night and morning most of the carriers decamped; some mischievous person having industriously spread the report that as soon as we crossed the river Quilo the natives would fire upon us, and cut the bridge to prevent our retreat, and that the King of Makouta had collected all his men to oppose our advance; and although we did our best to convince them that no such thing would happen, that the King of Makouta had received our presents and invited us to come to him, and was therefore our friend, our words were without effect, the stampede had commenced, and nothing could arrest it; the only plan, as time was so valuable to us, was to set to work immediately to procure others. There was a great hubbub in the square to-day between the chief of this town and our King's secretary, who was advising the remainder of the carriers to bolt, the chief saying he would post his men on the road and shoot the first carrier that attempted to pass. At 2.30 the chief of Vindu arrived with seventy carriers; 
and considering that was exactly the number that bolted last night, it looks uncommonly like an arrangement between our King and the chief of Vindu (who is his brother), or the people of that town and our carriers. There was great trouble in settling with the new men, who wanted the same quantity of cloth that we had originally given at Congo to come the whole distance; but as the journey had already been paid for three times over, it was necessary to make a fight for terms and reduce their exorbitant demands.

On the 15 th of July we made a start, and in half an hour reached the Quilo River, which we crossed by a native suspension bridge, exceedingly strong and well constructed of monkey-rope ; it would bear ten carriers with loads, but oscillated so that many of them preferred crawling to walking. The river was very low, being the dry season: it is said to be swarming with alligators, and we were afraid we should lose some of the donkeys in swimming them across ; but fortunately got them over safe, about half a mile below the bridge where there was less water. Having paid four pieces of cloth to the chief of Banyanga, who collects the bridge tolls, we passed on through his village, and crossing the Luanga River reached the town of Lāquā, where we remained for the night. After crossing the Quilo River, the aspect of the country changes; there are remarkable and abundant outcroppings of limestone rock, some rising abruptly from the grassy plain to an altitude of 100 feet, and from their weather-beaten appearance resembling rocks in the sea. The soil has also changed from brown to blue clay, of which the native pots and pipes are manufactured at Makouta. The following day we passed through a large grassy plain (a swamp in the rainy season), and reached the small village of Muncola, where the carriers came to a halt, and positively refused to proceed any farther; and when we sent for the King, he said it would first be necessary to send a messenger ahead with a present and await his return. To guard against excuse for the carriers bolting, this was done; but then no guide could be found under any promise of payment to take the messengers to Tungwa; fortunately we had one man who knew the road, and he with three others were sent. They returned at 8 P.M., having delivered the present to the chief, who said it was all right; but that as our present to the King of Makouta had miscarried, and he was the principal, we must send him another, which was accordingly done, the men starting early on the following morning. Shortly afterwards there was a free fight, with knives and sticks, amongst the carriers, and then word was sent us that they must have three fathoms more each before they would move the cargoes. An offer was made them of four pieces of cloth, which some were 
inclined to accept as it was only $2 \frac{1}{2}$ hours' farther journey to Tungwa; but in the middle of the negotiations, a messenger arrived, stating that our King and all his followers were bolting out of the village as fast as their legs could carry them, and, of course, the remainder of the carriers immediately followed suit. We sent, and the chief of the town also, to stop the King, but to no purpose. At the time we were at a loss to account for this sudden stampede; but heard afterwards that word had been sent to the King of Kilembella, that if he attempted to go to the chief's town with us his head would be struck off. Being anxious to reach Tungwa as speedily as possible, I started with one man, and after a smart walk of $2 \frac{1}{4}$ hours arrived at the market-place, where I was requested to wait until my arrival was announced to the chief. Shortly there arrived a head-man with about forty of the townpeople: he told me they were busy with the burial of the chief's son (which accounted for the firing of guns and tom-tomming that was going on), that in the name of the chief he was very glad to see me, but could not understand what a white man was doing such a long distance from the big water. I explained our mission, and requested him to ask the chief to supply us with carriers to bring us on without delay, and asked to be allowed to enter the town and visit the chief; he returned, promising speedily to send an answer. I was kept waiting till after sunset, when our own messengers returned, bringing back with them all the presents that had been sent, with a message to the effect that we must not pass by that road, as their father had forbidden it, and that they would not supply us with any carriers. As nothing more could be done that night we returned to the village of Muncola; and the next morning went again to the market, accompanied by the chief of the village and three or four men, bearing presents, and invited the chief of Tungwa to a council to state his reasons for refusing the road, after receiving our first messenger from Congo, accepting the presents, and inviting us to come. The palaver lasted nearly the whole day, and ended most unsatisfactorily. They would not accept our presents, nor give us carriers on the road; their father had forbidden it, and therefore the matter was out of their hands. Finding no amount of coaxing or presents would have any effect upon them, we concluded it better to return to Muncola and arrange carriers to take us to Kinsuka, and skirting the territory of Makouta, reach Sundi or some other part of the river. We were the more inclined to adopt this plan as the season was already well advanced, and time was of the utmost consequence to us, if we intended to be of any assistance to Dr. Livingstone. Had we not 
been encumbered with baggage, we might easily have pushed past these people and gained the river: but our duty was plainly to reach the Doctor with sufficient goods for his party and our own.

Tungwa is by far the most populous and best built town we have seen; the streets are regularly laid out and cleanly, the people are ivory traders, and the whole place has an appearance of prosperity. Our interpreter said the chief had in his house chairs, tables, and every article of European manufacture that is traded with, and lives in comparative luxury: he looked upon our presents as being very insignificant. The estimated population is about 1600 . The river, which rises from a fountain about 8 miles to the eastward of the town, flows round three sides of it, the fourth having a background of hills, the slopes of which are cultivated. The banks of the river are thickly wooded, and bananas and palm-trees abound round the town. Since crossing the Quilo River we have noticed the natives are smaller in stature and of a lighter colour, this being especially remarkable with the Tungwa people. Banza Makouta, the residence of the King, is a large manufacturing town, lying in a valley to the northward of Tungwa: it is noted for pottery, pipes, mats, and grass-cloths. The surrounding country is very fertile and well cultivated, producing sugar-cane, corn, ground-nuts, mandioca, yams, beans, \&c.; poultry, sheep, and goats are also plentiful. The River Tungwa flows past the western portion of the town. The chief of Muncola gave us a great deal of trouble, would not allow his people to sell us any provision, and was constantly sending us threatening messages, and delayed procuring us carriers until he found we were determined not to leave until he found the men. After four delays we succeeded in obtaining the requisite number, and began in the morning retracing our steps, reaching Lāqua in a few hours, where the carriers all bolted from us again; but as the chief immediately offered to supply their places, it was easy to see what arrangement had been arrived at. Unfortunately it is the custom of the country to make all payments before starting. We often foreseeing the inconvenience of it, and how completely we were at the mercy of the chiefs and carriers, tried to break through the custom, but to no purpose, they would not touch a cargo until all had been paid for-the usual trouble here; and as the distance to Banza Umputa was only a little over 4 miles, we determined to move the cargoes with our own men, seeing which the natives rushed in a body and cut the bridge over the river. This was rather too much of a joke; so I marched, revolver in hand, to the chief's house, and taking possession of him, gave him to understand that unless it was repaired in twenty minutes, I would shoot him and 
burn his town. He disclaimed all knowledge of the affair, and had the bridge hastily repaired, the carriers accepted the cloth they had already refused, picked up the cargoes with alacrity, and hastened on; but the moment they had crossed the Quilo River by the bridge, they dropped their burdens and ran for it, and we were some hours collecting it all at the Banza. The following morning we started four men, accompanied by two appointed by the chief of this town, to Kinsuka with presents and a demand for carriers; they returned next day, having reached as far as Zonzo (the next large town to Kinsuka), the chief of which refused our presents, saying the King of Makouta had sent him word that we had been refused the road, and asking him not to allow us to pass by his road. He said he was sure there was something wrong about us, or the King of Kilembella would not have run away at Muncola; that he did not trade, or his people; and he was perfectly satisfied to wear country cloth and use native mats; he did not want our presents or us in his country, and we had better go back to Congo and try some other road. Thus was our second chance lost; but knowing the influence of the King of Congo, and mindful of his promise to come in person and assist in clearing the road, L sent immediately to request him to come and bring with him the required number of carriers, as these people would not furnish us with any, except on condition that we went back, and we were naturally anxious to retain a position which had cost so much time and cloth. While the messengers were on the road to Congo, acting upon information, we despatched men to Tungwa with additional presents, and after five days' delay (during which time all manner of conflicting reports were received) they returned. A meeting of the chiefs took place, and they discussed our request for the road; the King of Makouta did not attend, but both he and the father of the chief of Tungwa refused to allow us to advance. The young chief who commands the eastern portion of the town sent me word that if we wauld return to Congo and procure 200 soldiers, he would "pat his stomach" (equal to an oath, and more binding) to me, and carry me with his own men to any place on the river I chose to name; he said he would first kill his father and burn his town-nice youth-and then dare the King of Makouta to interfere with him. Out of all the presents I sent by the son of the King of Congo-Lema-to the King of Makouta, he only received 8 fathoms of cloth, the remainder having been disposed of on the road. The messenger from Congo arrived, bringing intelligence that Congo town had been almost cleared out by small-pox; that the King was very ill with it, and all hope of assistance from him was at an end; so there was nothing left now but to speedily 
retrace our steps to Congo, and thence by the Embomma road to the river, and up the left bank. It was very disheartening to be thus thrown back, with the season so far advanced and the prospect of being dropped frequently on the road; but it could not be avoided, and we commenced collecting carriers at once.

We have found these country people to be exceedingly timid, superstitious, and suspicious, always imagining evil of us, although we acted in the most straightforward manner towards them, concealing nothing of our intentions, and mixing freely with them in order to accustom them to the white man. They thoroughly believed at Tungwa that we had come to find out about the ivory trade, and look for copper and silver at Sundi and Opombo, as the Portuguese had done at Bembe. In estimating the population, they take no account of the women and children, but only those who bear arms. Banza Umputa musters 136 men, of whom 130 have guns. They have five seasons to the year, which go by $2 \frac{1}{2}$ months. They reckon twelve months to the year: July, August, and half September, they call "Sevoo," or summer; half September, October, and November, "Bangala," or dry season; December, January, and half February, Māsanzā, or winter; half February, March, and half April, "Kundey," heavy rainy season; half April, May, and June, "Kintombo," or spring. Bangala commences when this (August) moon is finished. No rain falls until Bangala is finished; then follow two months' light rains, and then the heavy rains. September is the month for burning the grass all over the country, and it is also the hunting season; very few of them travel during that time. They calculate thirty days to the month. The marriage customs are rather peculiar. As soon as a young man has built himself a house, and can assure the parents of the girl that he has sufficient money to keep a wife, he can marry. Girls are betrothed at their birth, and the intended husband continues to make presents to the parents and give clothes to the girl until she arrives at the age of puberty, when she is handed over to him. In the event of a married man dying, if he has a younger brother, his estate and wives are handed over to him; if there is no brother, the wives go back to their parents, and the children are supported by the deceased man's family, and his property sold. They keep no account of the children's ages after they are two years old. A man is not allowed by "fetish" to cohabit with his wife, after the birth of a child, until it can walk alone. In every village there is what is called a young man's house. When a boy is about eleven or twelve years old he leaves his parents' house for this place (only returning for his meals), where he lives with the other young men until he marries. When 
chiefs are in mourning they never wash their faces; and, according to the degree of relationship, the period extends from three to twelve months. Pawning is carried on very extensively : a man will pawn his child, his gun, or his knife, to procure cloth or beads, when hard up, and if the pawnbroker does not choose to demand repayment, with interest, of what he has advanced, the property becomes his absolutely. Palm-trees are abundant, and average five bunches of fruit, equal to a gallon of oil, without taking into account the nuts, and bear two crops annually. This is all wasted-they say it is too much trouble to make it-and they are quite content with what they make by their ground-nuts. The country from this to the north and east is more open, the valleys are not so deeply undulating, the soil is rich, and, under cultivation, capable of producing anything.

After the usual delays and palaver, \&c., we commenced our march on the 15th of August for Congo, which we reached on the 29th of the same month, having been deserted by the carriers three times on the road. Here we found a wretched state of things: the King very ill, half the town dead, and everything looking very desolate; houses nearly all shut up. The men have disappeared, and the women wander about the town neglecting their farms and plantations. All is hushed : the clink, clink of the blacksmith's hammer, which so often reminded us of the villages at home, is no longer heard. I passed by his shed to-day, and found it ruined and deserted. There lay the anvil and the tools, and the remains of the charcoal fire; but the presiding genius, where was he? Gone, alas! like many, to the home of his fathers.

It was not till the 10th of October, owing to the great mortality amongst the carriers, that we were enabled to make a start from Congo for Banza Noki, where we arrived on the 22nd of the same month, having great trouble with the carriers on the road, who eventually deserted us at Banza Vokay, and we were compelled to employ fresh ones to reach the river. Here (Lucango) we found ourselves among friends: Mr. Pardo, of Boma, having a factory at this place, and he kindly placed the house at our disposal. We found the river had already risen 4 feet, and they say it continues to do so until the 21st of December, when it begins to fall. There is a steady current and stream at present of about 5 knots, breadth 850 yards. Finding after inquiries that the kings on this side of the river would not allow us to go to Yellalla, we crossed to the opposite shore, north side of the river; and, having pitched the tents, erected huts, and housed the baggage, we paid some visits to the neighbouring kings to arrange carriers, but they all stated that the season was too far advanced, the rains had already commenced, 
and they could not supply men until they were over. Finding, after repeated attempts, that nothing could be done, we commenced preparing our winter-quarters ; cleared some land, and planted it. We remained here until the 11th of December; but as the natives would no longer sell us food, and we could not catch enough fish or shoot game to keep us, we were compelled to break up the little colony and go down the river to Mussuco, where we were very hospitably received by Mr. Pardo, who was just re-opening a factory there. We built houses for the men, and had a store-place at disposal for the cargoes.

We remained at this place until the 10th of April. During the time made frequent excursions to the different chiefs both on the north and south banks of the river, negotiating for the road; and eventually succeeded, by making very handsome presents to Anelongo (the King of Banza Noki), in gaining him over. Commenced moving out of winter-quarters on the 10th of April ; and on the 17th of same month heard with profound regret of the death of Dr. Livingstone through Captain Hopkins, who ascended the river on purpose to meet us and give the intelligence. But conceiving it our duty to proceed, we pushed on, and had just completed arrangements for crossing the river above the falls, when the letter of recall from the Society overtook us; and, complying with instructions, we, with many regrets at the idea of leaving our work unfinished when all seemed so full of promise, commenced preparations for the return, leaving good presents with the chief in order to procure a good reception for those who might come after us. The Congo, which is one of the grandest rivers of the universe and still unexplored, is navigable for steamers to a distance of 110 miles from its mouth even in the dry season; it floods twice annually, the first and great rise taking place from 10th December to 23rd December; the second from the first week in March till nearly the end of June. In 1873 it only rose 9 feet 6 inches with the first flooding, and 2 feet with the second. A very low run was expected at the end of August of this year, owing to the small quantity of rain which fell. There are hundreds of canoes on the river, some of them capable of carrying 3 tons of cargo; and a very large trade in nuts and oil is carried on with them between Boma and the towns and markets above the factories. The natives are very skilful in the handling of their canoes, yet a great number of lives are lost annually through the swamping of their frail craft by whirlpools. They stand to paddle, singing the while; the large canoes have two men to steer and six to paddle. They choose the early morning for descending the river, when there is no wind. The 
fishermen use nets shaped like a spoon; they select dark nights for their work, one man holding a lighted brand over the water whilst the others dip up the fish, attracted by the glare, with the net.

For the guidance of future travellers in the Congo country, I would suggest that all carriers be engaged at Sierra Leone, where any number can be obtained for $1 s$. $3 d$. a day. From my experience of them I can safely say they will be found to answer every requirement; and the employment of them would render an expedition entirely independent of the natives, who by their cowardice and constant desertions entailed upon us heavy expenses and serious delays.

Mr. Monteiro regretted that Lieutenant Grandy did not pierce further into the interior, so as to obtain some idea of the course of the Congo. His own observations in Angola, to a distance of 150 to 200 miles inland, seemed to point to the conclusion that the Congo suddenly takes a bend south, and drains the whole of the country at the back of Angola to at least $15^{\circ}$ south latitude. Throughout the whole of that region there is not a single river worthy of the name. The land rises gradually from the sea coast until it becomes a sort of plateau, similar to Young's Land. He did not think the Congo came from the north, as there are four known rivers in that direction. The period of the Congo floods, too, corresponds with the rainy season in Angola.

Lieutenant Grandy, in reply, said he believed, with Mr. Monteiro, that there was a southern branch of the Congo. The information he obtained from the natives was that it was called Coanga by some, and Quango by others. It was, however, equally possible that the Congo had a northern feeder as well. This conclusion was arrived at from the second flooding of the stream, which only gives a small rise of about 2 feet. It was, however, almost an impossibility to obtain any information about the interior from the natives, who are excessively suspicious of Europeans. Immediately a question is put to them, they imagine that there is some sinister motive connected with it, and either evade giving an answer or tell a palpable untruth. The only traders in the country at present are those who travel with large caravans from Zombo, crossing the Congo somewhere in the neighbourhood of Sundi, and advancing towards the Manyuema country. It was evident that they are accustomed to encounter considerable opposition, because they travel from 500 to 800 strong, all armed. They make their trip once a year, going and returning in the dry season. He met one such caravan of 500, while staying at Congo, and questioned them particularly about the interior, but could get no satisfactory answers. So long as an expedition is dependent upon the natives for carriers, failure must ensue. Carriers should be obtained at Sierra Leone, or some other port on the coast, and should be well armed. Unless such precautions were taken, it was impossible to penetrate into the interior.

The Rev. Horace WaLLER said that he had received that evening the last portion of Dr. Livingstone's map - a little slip bearing on his route from the East Coast to Lake Nyassa. It was very much stained and travel-worn, but it would no doubt afford the missing link to the map of that region. In the Doctor's original pocket-book there was a little sketch of that part of Tanganyika which Lieutenant Cameron had recently visited, and in that sketch the river Logumba was made to flow into Tanganyika.

The President : After that, he states that it flows out. 
The Rev. Horace WALLER said it was most unfortunate that the names of the rivers were so much alike. In many cases, too, the same names were repeated several times. It was impossible to deal with such a difficult question on the spur of the moment, and he trusted that an opportunity would be afforded for renewing the discussion at a future date. It would be fair towards the subject in general, and Lieutenant Cameron's statement in particular, to defer it till his maps and journals were in the possession of the Society.

'The President said that this identity of the Lualaba with the Congo was a very interesting question, and was practically the only remaining great problem to be solved in African geography. All the evidence that had been collected, especially by Dr. Behm and Mr. Keith Johnston, as to the physical geography of the country, seemed to render their identity as nearly a matter of certainty as anything could be that had not been tested by observation. Great credit was due to Lieutenant Cameron for what he had done, and also for recovering Livingstone's papers, which otherwise would have been left at Ujiji for any chance traveller. With regard to Lieutenant Grandy, he was sure the Meeting would return him their very best thanks. That he had not been more successful in his attempt, was owing to no fault of his. It really did seem as if it were an absolute impossibility to pass into the interior to the south of the Congo, unless the expedition were supported by independent porters and attendants. From what they had heard of Lieutenant Grandy's experience, it was very unlikely that the German expedition would meet with success. If they proceeded to the north, they no doubt would be more likely to prosper.

Lieutenant Grandy said that the last news he heard before leaving was that the German expedition had been thrown back.

Fourth Meeting, 11th January, 1875.

Sir RUTHERFORD ALCOCK, K.c.B., Vice-President, in the Chair.

Elections._-William Powell Branson; James Broadmead, B.A.; Andrew Cassels (Member of the Council of India); Alfred Craven; Edward Maynard Denny; Lieut.-Col. James Henry Dowling (Gloucestershire Engineer Volunteers); Joseph John Dunstone; Matthew Hamilton Gray; Alexander S. Harvey; Augustus John Harvey; Charles Heneage; Frederick Hollebone; Captain John W. Hozier (Scots Greys); Colonel Archibald Impey-Lovibond, R.E.: Edward Marston; P. Venkatakrishnama Naidu; William Nesbitt; Staff-Commander D. Pender, R.N.; Rev. John Eade Pryor; Thomas Alex. Ridpath ; James H. Russell; Arthur William Sadgrove; Rev. Robert Salthouse; J. C. Stirling; Edward Swain; Lieut.-Col. William Tedlie; Captain Frederick Trench Townshend (2nd Life Guards).

Presentation.-F. A. Gwynne, Esq.

Donations to the Library, 14th December, 1874, to $11 \mathrm{Th}$ JANUARY, 1875.-Tenth Report of the Board for Protection of Aborigines, Victoria, 1874 (The Australian Government). Observations sur l'Helix ligulata de Madras, 1869, and Quelques Obser-

VOL. XIX. 